\title{
Article \\ COVID-19 and Religious Freedom: Some Comparative Perspectives
}

\author{
Javier Martínez-Torrón ${ }^{\dagger}$
}

check for updates

Citation: Martínez-Torrón, Javier. 2021. COVID-19 and Religious Freedom: Some Comparative Perspectives. Laws 10: 39. https:// doi.org/10.3390/laws10020039

Received: 12 April 2021

Accepted: 8 May 2021

Published: 18 May 2021

Publisher's Note: MDPI stays neutral with regard to jurisdictional claims in published maps and institutional affiliations.

Copyright: (c) 2021 by the author. Licensee MDPI, Basel, Switzerland. This article is an open access article distributed under the terms and conditions of the Creative Commons Attribution (CC BY) license (https:// creativecommons.org/licenses/by/ $4.0 /)$.
Complutense University of Madrid, 28040 Madrid, Spain; jmtorron@ucm.es

† Professor of Law, Complutense University of Madrid; President of LIRCE (Instituto para el Análisis de la Libertad y la Identidad Religiosa, Cultural y Ética).

\begin{abstract}
The government's measures against COVID-19 have raised, in virtually all contemporary democracies, important issues regarding the proportionality of limitations on fundamental rights, including freedom of religion or belief. This paper analyses some of those issues with particular reference to religious freedom, in the light of the experiences of various European and American countries. It also examines the cooperation (or lack of) between governments and religious communities in the fight against the pandemic, as well the response of religious communities to anti-COVID-19 rules, which has included recently some litigation alleging the unequal treatment of religion in comparison with other activities or institutions. The author argues that more dialogue and reciprocal cooperation between governments and religious communities (and civil society in general) is needed in this type of crisis, as well a strict scrutiny of restrictions imposed on freedom of religion from the perspective of proportionality and equality.
\end{abstract}

Keywords: COVID-19; religious freedom; fundamental rights; discrimination; proportionality; cooperation between government and religious communities; public health

\section{The Coronavirus Crisis as an Opportunity for Social and Legal Analysis}

I must begin with a caveat. These brief pages are not intended to perform a deep or exhaustive analysis of a very complex subject. They merely contain, in response to a kind invitation of professor Adelaide Madera, some initial personal reflections upon the impact that the pandemic of COVID-19 has had-and still has-on religious freedom and the relations between the State and religious communities. These reflections should not be taken as definitive, among other reasons, because the pandemic is still evolving and so are government policies in the five continents. Being this a global phenomenon, I will adopt here a comparative law perspective and will commence by recognizing that I am indebted to some collective volumes that have been published in the last months and provide insightful comparative studies ${ }^{1}$.

Contemporary societies, especially in the West, have been accustomed for decades to the absence of new challenges that could seriously endanger or question their foundations. This has all changed with the emergence of COVID-19. Admittedly, we have had grave pandemics in the past. One century ago, the $1918 \mathrm{flu}$ (also known, improperly, as the "Spanish $\mathrm{flu}$ ") caused millions of deaths around the globe. ${ }^{2}$ And some other-lesserpandemics came after that, including the 2009 swine flu. The COVID-19 crisis is not strictly speaking an unprecedented health crisis but some of its characteristics make it different from others. First, we must consider a biological factor: leaving aside the lethality

1 In particular (Consorti 2020a; Balsamo and Tarantino 2020; Martínez-Torrón and Lara 2021). The latter volume, and my own chapter in it, have especially inspired these pages. See also (Soler Martínez 2020). For the rest, I will try to keep bibliographical references to a minimum.

2 The actual number of victims caused by the $1918 \mathrm{flu}$ remains unclear after decades of studies-with a tendency to raise the figures with the passage of time. More or less recent studies suggest a death toll of between 50 and 100 million (Johnson and Müller 2005). I am grateful to professor John Eicher, Fellow at FRIAS in 2020-2021, for bringing this work to my attention. 
and mortality indexes, the SARS-CoV-2 is a virus that is transmitted with tremendous facility, mutates fast, and is proving to be particularly resilient. Second, since it was first detected, the virus has spread very rapidly and uncontrollably because of the mobility of the population all over the world nowadays. And third, the reaction of people has been different.

A certain "complex of invulnerability" has been for years one of the idiosyncrasies of present-day societies, particularly in the more developed areas of the planet. After the Second World War and once disappeared, long ago, the cold war and the threat of a nuclear catastrophe, our societies took for granted that no factor-external or internal-could actually endanger them. Yes, from time-to-time we knew of a tsunami, an earthquake, a "little war" here or there; or some epidemics, especially in Asia and in Africa. However, those were things that "occurred to others". Even AIDS caused by HIV was supposed to affect mostly certain groups of people or geographical areas. For most people, the biggest global concern in recent times has been climate change, which still appeared too far in the horizon and too "intangible" as to cause proper fear. And perhaps, since 2001, also jihadist terrorism; but this has been mentally "digested" as producing isolated attacks that normally also hurt "other people".

COVID-19 has changed this state of mind. Wrapped up in the feeling of safety produced by technological advance, as well as by a systematic and deliberate distancing from, and softening of, the experience of death, Western societies have experienced real and serious fear for the first time in decades. Many people fear for their lives, for their families, for their economy, for their jobs, for their future-virtually for everything. This has made them accept more or less easily-or at least without resistance-the restrictions imposed by authorities to contain the disease. By contrast, some other people, tired of the substantial changes that coronavirus has brought to their routines, have decided to act in recent months as if nothing grave was happening.

The fact is that the 2020 pandemic has affected all areas of social life, including the law. Some of the problems raised by COVID-19 are new, especially in matters of science and public health. In other areas, however, the pandemic has not in rigour raised new questions but rather unprecedented circumstances in which it is necessary to deal with already familiar questions. This is what, in my view, has occurred in the legal arena and in particular in the field of human rights. In this sense, COVID-19 has served to cast new light on how our legal systems face issues that are essential in our conception of the rule of law, and manifest with special clarity in moments of crisis.

For that reason, from a legal perspective, if we focus exclusively on the concrete situation caused by COVID-19 we would miss the key point. All epidemics end sooner or later, one way or other, with some consequences or other. In my view, it is more important to concentrate on what this pandemic teaches us about ourselves, that is, about our societies, our conception of political organization, our understanding - and guaranteeof fundamental rights, including freedom of religion or belief. We should take this as an opportunity to recognize our societies' strengths and flaws-what should be preserved or improved, what is dispensable or unacceptable. As in individuals going through a personal crisis, the coronavirus pandemic brings up the best and the worst of every society. Identifying and distinguishing those elements, and proposing solutions when appropriate, is one of the significant contributions that a jurist can make in these times.

\section{Governmental Measures Against the Pandemic}

Simplifying a complex reality, we could say that governmental measures against COVID-19, in every country, fall into two broad categories: measures aimed at fighting the virus and its expansion, and those others that are meant to mitigate the pandemic's consequences for economy and public health. Both types of measures deserve the jurists' attention. We even could add another relevant element for the legal analysis of the coronavirus pandemic: society's reaction to the government's measures-a reaction that can trigger new measures or move to the modification of the existing ones. 
As everyone else, jurists understand that exceptional circumstances call for exceptional measures of government. However, this exceptionality raises also a certain concern in the legal world, especially with regard to two aspects of governmental action. On the one hand, the effect of measures adopted during the pandemic on the essential procedures of democratic governance-in particular, the extraordinary regulatory powers assumed by the executive, which have led to a simplification, and sometimes a cancellation, of parliamentary control (as well as a certain deferential attitude on the part of the courts). On the other hand, the strict limitations imposed on fundamental rights, which would have been otherwise unconceivable; the fundamental rights that have been most affected are probably freedom of movement, freedom of trade and entrepreneurial freedom in general, freedom of assembly, the right to respect for private and family life, the right to education, and of course freedom of religion or belief.

The problem with extraordinary powers is that governments get easily accustomed to have them and to exercise them. The longer governments are in possession of them, the more comfortable they feel in that position. It is a natural human tendency. Precisely because of that, the time factor is here especially relevant. As time passes by, and once the most immediate urgent measures have been taken and the initial uncertainties about the nature and expansion of the pandemic begin to wither away, jurists begin to raise legitimate questions about two issues: if keeping the executive's extraordinary powers is still justified, and the precise justification of specific restrictions on fundamental rights from the perspective of their necessity and proportionality (their legitimate aim-the protection of public health-is not in question).

The first word that comes to mind in this respect is accountability. It is not a matter of a lack of trust in the government, or of adopting attitudes of scepticism or negationism. It is just that citizens have the right, and the reasonable expectation, to be explained why their rights are still being limited and why the normal procedures of democracy and parliamentary control are not yet fully functional. Governments must be accountable and transparent. Otherwise, the broad discretion they are recognized under these circumstances may easily transform into arbitrariness.

This is the reason why, in every country, legal scholars have examined with a critical eye the legal norms and policy measures adopted by governments to control the expansion of the pandemic, in order to scrutinize their actual consistency with the constitutional framework and the whole legal system. ${ }^{3}$ Such analysis has been performed following a variety of criteria, which include the requisites established to declare a state of emergency or alarm, as well as the respective competences of the executive and legislative powers in these situations. The latter aspect is particularly complex in countries with a decentralized structure, where the distribution of competences between the different levels of the State's organization often was not designed taking into account emergencies of this nature, seriousness, and global dimension. ${ }^{4}$

In countries with a federal or regional structure, normative production and consistency becomes more intricate, and the possibility of confusion or even conflict between rules is higher than in centralized States, with the consequence that the national legal chart may become irregular. Thus, a legal scholar has expressively described the initial Italian normative construction of measures against COVID-19 as a macchie di leopardo (leopard-design; Consorti 2021, p. 171)-i.e., heterogeneous and uneven, and maybe not as beautiful as that feline's fur. Something similar has been said about the legal situation in Spain, Brazil, Argentina and Mexico. Conversely, in Germany the federal government was determined, since the very beginning, to coordinate its action with

3 The legal literature about this issue multiplies at incredible speed, but it is still enlightening to see the early studies published in the first months of the pandemic. In Spain, see for instance, from a general perspective (Sieira Mucientes 2020); see also the contributions of different authors gathered in the special issue 86-87 of the legal periodical (El Cronista del Estado Social y Democrático de Derecho 2020).

4 Normally, the type of emergencies that legislators had in mind when organizing the distribution of competences were military (war), political (insurrection), or the result of natural catastrophes such as earthquakes or storms. A global pandemic was not probably considered, and even less in the last decades. 
that of each of the Länder's government (Mückl 2021, pp. 76-83; Rodrigo Lara 2021, pp. 125-42; Navarro Floria 2021, pp. 312-34; Souza Alves et al. 2021, pp. 361-67; and Patiño Reyes 2021, pp. 460-76).

The level of constitutional meticulousness when regulating emergency situations has been another element of uncertainty. The less precise a national Constitution is in this point, the more unpredictable are the reach and duration of the powers that the central government can assume in these circumstances. The problem aggravates if there is, in addition, an unstable political situation, as occurred in Belgium since the May 2019 elections - which caused the paradox that a government that was initially constituted to take care of ordinary business (affaires courantes) ended up being transformed by Parliament into a temporary government endowed with special powers for half a year (Christians and Overbeeke 2021, p. 102).

In any event, some recent analyses of a representative sample of European and American countries ${ }^{5}$ suggest that, despite many constitutional and structural differences between those countries, they tend to share a common characteristic: the lack of clarity in the measures adopted by their governments. Such lack of clarity can be observed in those measures that, declaredly based on technical criteria, were aimed at protecting public health through restrictions on fundamental rights, as they prohibited or imposed certain conducts. Especially in the first months of the fight against the pandemic, sometimes there were even contradictions between rules as well as a continuous change of criteria, which raised in many people a reasonable suspicion that governmental action was pervaded by improvisation and amateurism.

This fact, even if we cannot judge here the actual impact of those limitative measures on containing the pandemic, had an important effect-the confusion caused in and perceived by citizens. Such confusion led to legal uncertainty and to an increasing scepticism of a large part of the population, not convinced that the measures were appropriate and proportionate. This, in turn, had obvious consequences for the degree of acceptance of and respect for the rules, and therefore for their efficacy. ${ }^{6}$ As a US scholar wrote with regard to his country, the effects caused by the citizens' lack of trust in their government and their public institutions are potentially more harmful than the effects caused by the pandemic itself (Scharffs 2021, pp. 447-51). This is not an overstatement; we can see in recent months that, even though the rules are now definitely clearer and more precise, a feeling of incredulity about their efficiency has been spreading in the population of most countries (also fuelled, no doubt, by a parallel feeling of impatience and despair vis-à-vis the prolongation of an exceptional situation that nobody could predict at the time of the pandemic's outburst).

Some comparative legal studies ${ }^{7}$ show also that virtually in every country a number of concerns have been raised about the legitimacy of the restrictions on fundamental rights, both from the point of view of procedure and substance. With regard to procedure, three main points have been discussed: to what extent the government respected the proper legislative channels after the first weeks of the pandemic, marked by uncertainty and by the urgency to adopt measures that could help save human lives; to what extent the central government coordinated its activity with regional and local authorities; and to what extent the main actors of civil society were consulted and their cooperation to fight the pandemic was actively sought, instead of relying on the exclusive official resources and personnel.

With regard to substance, the main issue has been the actual proportionality of the limitations imposed by governments on the exercise of various fundamental rights. Naturally, a judgment of proportionality in these circumstances must be based on scientific and technical criteria, and it seems sensible to recognise a wider discretion to governments in this regard considering that there is still a large margin of discussion and disagreement

\footnotetext{
5 See the different chapters of (Consorti 2020b; Balsamo and Tarantino 2020; Martínez-Torrón and Lara 2021).

6 (See ibid).

7 (See especially ibid).
} 
among scientists about key aspects of the spreading of COVID-19 and the most efficient means to fight it. Nevertheless, to be legally acceptable, limitations on fundamental rights must be justified with a reasonable degree of specificity and not just by vague references to risks for public health. If citizens must yield large parts of the exercise of their fundamental rights they are entitled to know why. Here, the time factor plays an important role; the more time passes by, the less urgency exists-because there is more knowledge about how the virus works and can be contained-and therefore the more precise must be the governments in justifying the necessity to restrict certain rights of the population. Extreme limitative measures that would be easily obeyed at the beginning of the pandemic could seem less acceptable as the months went forward. I will return to this point in Section 6 of this paper.

\section{The Justification of Limitations on Freedom of Religion or Belief}

As has occurred with other fundamental rights, the general legal and policy measures adopted by governments to control the pandemic have had an impact, direct or indirect, on the exercise of freedom of religion or belief, especially in the case of religious believers and religious communities. From the perspective of religious freedom there are, in my view, four thematic areas of special interest: the legal regulation of the fight against coronavirus; the equal treatment of religious freedom in relation to other fundamental rights; the cooperation between the State and religious communities; and the reactions of religious communities to governmental measures. When dealing with each of these areas it is important that legal scholars keep a balance between a critical analysis of realityneither submission nor resignation should be characteristics of a jurist-and the interest in providing solutions or suggestions that may contribute to improve one's own legal system.

With regard to the first of these areas, what I wrote in the previous section about fundamental rights in general is applicable to freedom of religion or belief; and vice versa, so that much of what is being said below about religious freedom would apply to freedom of assembly or freedom of trade, for instance. As is well known, according to international standards and jurisprudence, ${ }^{8}$ limitations on religious freedom must, in the first place, pursue a legitimate aim; in the case of the measures adopted against the COVID-19 pandemic, it is undisputed that they pursue the legitimate aim of protecting public health, as well as the rights and freedoms of others. In addition, such limitations must be deemed necessary, and not only useful or convenient. Establishing the necessity of a restriction on religious freedom - as in any other fundamental right-entails a judgment about the existence of a relation of proportionality between the restriction in question and the aim that it is declaredly pursuing.

There are different criteria to determine the proportionality of a limitation, depending on the fundamental right we deal with and on the concrete circumstances of the case. However, when we look specifically at the limitations on religious freedom caused by measures adopted against COVID-19, we can identify prima facie two criteria that are especially relevant.

One of them is the duration of the restriction, which is of great significance if we take into account that such restrictions affect almost always the freedom of worship-collective as well as individual-and the religious assistance to people who are in a situation of particular vulnerability, such as being in a hospital, perhaps with the prospect of near death. In other words, it is important to justify not only which limitations can-or mustbe imposed on the practice of worship or on religious assistance, but also for how long they will be held. The temporal aspect is essential here because for believers-and for their churches - there is a big difference between eliminating, or severely reducing, the possibility of worship and religious assistance for two weeks or for several months. This applies to regular or periodical religious worship as well as to episodic ceremonies that

8 For a detailed explanation, (see Gunn 2005; van den Vyver 2005; Martínez-Torrón 2005). With specific reference to public health as a legitimate justification for limitations, (see Payne and Doe 2005). 
have unquestionable significance, such as baptism (or its equivalent in non-Christian religions), weddings and funerals among others.

The other especially relevant criterion is the equal treatment of religious freedom visà-vis other fundamental freedoms that have been subject to qualitative and quantitative limitations as a result of anti-COVID-19 actions. The State must not only prove that certain restrictive measures are necessary, it is obliged also to regulate and apply those measures in a way that is neither arbitrary nor discriminatory. Religious freedom should not be either privileged or discriminated in relation to other fundamental rights. For instance, it would not seem reasonable to request a different safety distance between persons in churches, or dissimilar occupancy rates, in comparison with supermarkets, museums or theatres. However, religious freedom, as any other fundamental freedom, does require a specific legal treatment that is based on an appropriate comprehension of the importance or centrality that certain acts of worship or religious assistance have for the doctrine of churches and religious communities as well as for their members' practice of religion.

\section{Equal Treatment and State's Religious Neutrality}

This leads us to consider some immediate question. To what extent can a religiously neutral State-as is normally the case in Europe and America-define which aspects of the practice of religion are essential and therefore deserve to be recognized as an exception to rules that restrict freedom of movement and freedom of assembly? ${ }^{9}$ Are the State authorities entitled to decide by themselves which expressions of religious worship must be included in - or excluded from—-those "essential services" that will be allowed to function during a situation of emergency or alert, in the same way they take such decision with regard, for example, to pharmacies, supermarkets, public transportation or accommodation services?

The relevance of this question is not circumscribed only to the discussion about the degree of rationality or consistency shown by public authorities when they select the services considered essential for society (this issue raised a heated debate in Spain and in Brazil when, at the very beginning of the declaration of the state of emergency, barbershops and beauty parlours were included among those essential services that were authorized to remain open; (Rodrigo Lara 2021, p. 120; Souza Alves et al. 2021, p. 360). Beyond that first layer, there is a deeper question that relates to the legal notion of discrimination. In order to assess if a differential legal treatment is discriminatory or not, the first criterion consists in determining if such difference is based on a "reasonable and objective justification". ${ }^{10}$ Certainly, it is not easy to reconcile the State's religious neutrality with a judgment of public authorities deciding if religious worship-be it collective worship or individual worship practiced in a temple-is or not "sufficiently essential" to be distinguished, on a "reasonable and objective" basis, from other more dispensable activities.

Public authorities cannot be deemed qualified, either intellectually or legally, to make such a judgment by themselves, without counting on the view of the relevant churches and religious communities (each religious community has its own rules concerning the mandatory character, and the dispensability, of various manifestations of worship). This is a consequence, in certain countries, of a constitutional principle. But it is also a consequence of the international standards on freedom of religion or belief-we can infer from these standards that States are obliged to keep a certain religious neutrality in order to guarantee an adequate protection of religious freedom on equal conditions for all individuals and groups. Indeed, the State's religious neutrality has received progressive attention on the part of international jurisdictions, especially in Europe ${ }^{11}$ considering that this is not

9 The question was raised by Professor Rafael Palomino in an international seminar held at Complutense University on 13 November 2020. For a detailed explanation of his ideas on this point, see (Palomino 2014).

10 This is a common and well-known judicial doctrine. In the case law of the European Court of Human Rights, it dates back to 1968 (Belgian linguistic case). For an analysis of the principle of equality in the Strasbourg Court in the context of other European institutions, see (Besson 2012). For a summary of criteria and case law of the Strasbourg Court, see (European Court of Human Rights 2020).

11 For a comprehensive and insightful study of the Strasbourg Court's jurisprudence on the State's religious neutrality, in the light of the constitutional principles of France and Germany, see the doctoral dissertation of (Valero Estarellas 2017). 
something that can be left entirely at the disposal of national constitutions. The traditional doctrine that international conventions do not impose a particular system of relations between State and religion remains intact, for this is a delicate matter in which culture, history and socially accepted values play a crucial role. However, at the same time, it is gaining momentum the idea that without a minimum neutrality of the State and its institutions, it is not viable to provide full protection to religious freedom and to avoid some level of discrimination of all individuals and communities, especially minorities. ${ }^{12}$

If we look at the rules enacted against COVID-19, it is not difficult to observe a double tendency in the action of the governments of a number of European and American countries. On the one hand, a "weak", generic and ambiguous justification of the alleged necessity of the restrictions imposed on the freedom of worship. On the other hand, a relative lack of sensibility to understand how important are, for individuals and communities, some aspects of the exercise of religious freedom, which have been particularly impaired by the measures against the pandemic. Among these aspects is, of course, collective worship, which by definition implies the congregation of people in the same place, often a closed space. And we must include also the individual worship that is rendered in a church or place of worship, alone or in the company of other persons. For many people, to pray in a temple has a special meaning and cannot be easily replaced by other practices; this offers a particular nuance in the case of Catholics and Orthodox Christians because of the consequences of the theological doctrine of transubstantiation and the belief in the real and continued presence of Jesus Christ in the consecrated form. To that we can add religious assistance, which has a singular moral transcendence in the practice of the sacraments of penance and the anointing of the sick in some Christian churches. Moreover, in most religions there are collective rituals or ceremonies of remarkable significance, either because they must be performed at specific times of the year or because they are linked to special moments in the life of a person, such as baptism or rites with an analogous meaning, weddings, and funerals and burials.

Such lack of sensibility has some similarity with the attitude that can be seen on occasion in high courts, national or international, when they judge situations of conflict between religious autonomy and other fundamental rights. ${ }^{13}$ Sometimes, they tend to judge the reasonability of decisions adopted by religious authorities, or certain religious practices or ways of life, from a merely secular-or even personal-perspective. Moreover, they may take a similar approach with regard to the gravity of concrete interferences with the autonomy of religious communities. This often results in a "lax" evaluation of the necessity of restrictions imposed on religious freedom. Naturally, I am not contending that the manifestations of religious freedom, individual or collective, must always have priority over other legitimate interests that deserve protection, as public health in the case we consider here. But I would like to emphasize that, in order to assess the necessity and proportionality of limitations on the freedom of worship, it is essential to depart from a realistic appraisal of the true impact that those limitations have in the life of people and communities; and such appraisal cannot-and probably must not-be done by the State authorities by themselves, ignoring the religious frame of reference.

Certainly, religious autonomy is not absolute, and if needed, the State is entitled to impose coercively severe restrictions on worship to preserve public health in the circumstances of serious risk. However, the State's autonomy is not absolute either; it is subject to the principle of equality among other things. Therefore, restrictions on worship cannot be discriminatory in relation to limitations imposed on other freedoms and must be adopted on the basis

12 With specific reference to Europe, see in Spain (Cañamares Arribas 2019; Valero Estarellas 2019). See also (Martínez-Torrón 2018); and, from a broader perspective, (Martínez-Torrón 2015).

13 A recent and striking example of this is the case of Sandra Cecilia Pavez Pavez v. Chile, in the Inter-American jurisdiction, which involves the situation of a teacher of Catholic religion in a public school who was deprived of her licence to teach Catholic doctrine because of some public and lasting conduct that was considered immoral from the perspective of the Catholic Church. The opinion delivered by the Inter-American Commission of Human Rights completely ignored the religious autonomy perspective, as if the situation had no implications at all for religious freedom (cf. merit report No. 148/18, case 12.997, 7 December 2018). When I write this page, the case is still pending before the Inter-American Court of Human Rights. The report is available in: http:/ / www.oas.org/es/cidh/decisiones/corte/2019/12997Fondo-ES.PDF (accessed on 11 May 2021). 
of a reasoned judgment about the importance that a particular type of worship has for individuals and communities. And, as mentioned above, a neutral State should not make such judgment on its own volition but in dialogue and consultation with the relevant churches and religious groups.

\section{The Necessary State's Dialogue and Cooperation with Religion}

Indeed, if generally speaking it is considered a good practice that the State keeps channels of communication with civil society, in this area the dialogue and cooperation with the collective actors of religious freedom is imperative. To argue that State authorities can, for instance, unilaterally label some worship activities as "dispensable" not only is unrealistic but also risks weakening that delicate and important line that separates the secular and the religious as realms that possess their own reciprocal autonomy. In Western societies, State and religion live in a legal habitat that has been eloquently described as a "frontier system"; certainly, frontier conflicts are inevitable, but to abandon or blur the notion of frontier between those two realms has historically proved to be "lethal" (Navarro-Valls 2008, p. 105).

Furthermore, the importance of the time factor emerges here again. Initially, because urgent measures were needed, a momentary invasion of a central aspect of religious autonomy could be tolerated. However, once the urgency has passed, it is much less acceptable that the State continues to restrict, or even suspend, religious worship without an appropriate consultation process with religious communities. This is even less tolerable when, as occurred in Portugal, once the state of emergency was over and the constitutional normality restored, limitations on fundamental rights were kept on the sole basis of the government's will (Raimundo et al. 2021, pp. 231-38).

During the COVID-19 pandemic, in a number of countries of Europe and America, governments have approached limitations on religious freedom-and usually also limitations on other freedoms - with an attitude that is characterized by unilateralism, imposition, and improvisation, instead of turning to consultation, cooperation and reflection. This fact is disheartening, for we are in a situation that requires broad consensus on the measures and patterns of action to be adopted; the gravity of the circumstances calls for co-responsible deliberation and not for unilateral imposition-especially if it often appears to be not sufficiently informed (and sometimes uninformed). One of the collateral effects of such a deficient governmental approach has been the uncertainty raised among citizens about the precise reach of the limitations. To cite just a minor but revealing example, in countries such as Belgium, France, Italy or Spain, places of worship were never closed, not even during the pandemic's initial moments when the rules were most stringent (Christians and Overbeeke 2021, pp. 104-12; Fortier 2021, pp. 150-57; Consorti 2021, pp. 173-76; Rodrigo Lara 2021, pp. 130-38); but at the same time, governments did not foresee explicitly that going to a place of worship to pray individually was a legitimate exception from lockdown at home; hence, it was unclear if that was an involuntary legal oversight or if that meant that temples could be visited only when they were within the route to one of the authorized places or activities, such as a pharmacy or a supermarket.

On the other hand, in situations of crisis such as this pandemic, the cooperation between State and religious communities should not be circumscribed to a dialogical procedure in the determination of limitations to be imposed on religious freedom. It would have been advisable that governments, conscious of how important it was to use all available means and aware that the society's resources go far beyond those directly controlled by political power, had requested-or sometimes just accepted-the collaboration of the vast network of entities and institutions that form what we normally call the religious "landscape" of a country. Churches and religious communities have at their disposal means that can be immensely useful to face emergency situations. This includes institutions that have a religious ethos even though they do not have a proper relation of dependence on a church or religious community. For instance, health institutions, as well as religiously inspired 
NGOs and volunteers mobilized by organized religions to provide services to particularly vulnerable people and take care of them. ${ }^{14}$ Also, we could think of other less quantifiable or visible areas, such as spreading and explaining the anti-COVID-19 measures; raising in the population consciousness of the significance-also from a moral perspective- of complying with the government's rules and avoiding irresponsible behaviour that may endanger other people; identifying situations and sources of risk and conveying them to public authorities; and combatting the disinformation - be it the result of ignorance or of mischievous interests - and hate speech that tend to proliferate in these type of scenarios, etc.

Therefore, it is surprising that, in a number of countries, State authorities have insisted on fighting this battle practically solo, renouncing to count (or counting in a very limited way) on the cooperation of civil society, and in particular of the multidimensional universe of religious institutions. This was an ideal opportunity to build bridges and channels of collaboration between the secular and religious environments, united in a common cause which is easily comprehensible for everybody, irrespective of one's personal position in matter of beliefs. It is difficult to understand not only that in many places there has been no actual effort to create cooperation channels, but also the fact that some countries have not even made use of the already existing channels. This has been the case in Spain and Portugal, where, for what I know, their respective commissions on religious freedom have not been consulted or informed for months after the pandemic started. ${ }^{15}$

In any event, we should not forget that cooperation circulates also from the State towards religious communities - this is indeed what the Spanish Constitution explicitly provides. ${ }^{16}$ In Europe, because of the awareness of the positive contribution that normally religions provide to society, State cooperation with religion is often conceived as involving direct or indirect financing through a variety of national systems according to each country's tradition. ${ }^{17}$ In this regard, as a Polish scholar has suggested, one of the possible collateral consequences of the pandemic is a rethinking of the State economic cooperation with churches, taking into account that restrictions on collective worship have made more difficult the viability of customary ways of self-financing, such as collections during religious ceremonies or services (Brzozowski 2021, pp. 205-8).

\section{Reactions of Religious Communities to Governmental Measures}

The way churches and religious communities have reacted to governmental measures against the pandemic also deserves the jurist's attention. Sociologists are not the only ones interested in analysing the social behaviour in relation to State laws. This is also of interest for legal studies, for on the one hand, it has an impact on the norms' efficacy, and on the other hand, it can contribute to the norms' consolidation or, quite the opposite, to their reform or even their abrogation. Moreover, the analysis of the motives underlying certain reactions, especially the negative ones, may shed light on possible flaws or anomalies in the normative process, which in turn could explain the inadequate content of the norm in question and the reasons why it was socially rejected.

Except for some isolated positions of negationism or radical providentialism, ${ }^{18}$ by and large we can say that the vast majority of religious communities have initially acted in a sensible and responsible fashion with regard to the anti-COVID-19 rules enacted by the governments that imposed restrictions-sometimes severe-on freedom of worship (as well as on other fundamental freedoms). They acknowledged the gravity of the problem and recognized, explicitly or implicitly, the competence of State authorities to take rapid and drastic action. Furthermore, some churches and religious communities took the initiative

14 Clear examples of this activity are provided, in the context of Peru, by (Flores Santana 2021, pp. 507-10).

15 For a critical analysis of the Spanish Advisory Commission on Religious Freedom, from various perspectives, including some comparison with the Portuguese Commission, see the collective volume (Ministero de la Justicia 2009).

16 See art. 16.3 of the Spanish Constitution.

17 For a recent and clear analysis of the State economic cooperation with religion in Europe, see (Meseguer Velasco 2019).

18 Some examples of these attitudes in Asia, Africa and Latin-America are provided by (Consorti 2020a; Fattori 2020; Introvigne 2020; and Picciaredda 2020). 
before the government did or enforced self-imposed limitations on collective worship, or on the opening of places of worship, which went beyond the governmental measures. For instance, dispensing from the dominical mass in the case of Catholics, suspending collective prayers in mosques and synagogues, or even closing meeting places on their own volition. Such an attitude was prompted by natural reasons of prudence but also by loyalty and support of the government, irrespective of how much they were convinced of the consistency and accuracy of the scientific foundations flagged by the government when adopting restrictive measures (Christians and Overbeeke 2021, p. 99).

In this regard, it is significant the fact that many churches and religious communities opted for the self-restriction of collective worship and prayer even when most governments did not formally oblige to close the temples. The most common governmental solution was a limitation on the number of participants in collective ceremonies. In Germany, public worship was prohibited only for some weeks in almost all Länder, following the same criteria applied to any public event that involved the congregation of people (Mückl 2021, pp. 76-78). The Church of England has been particularly cautious and meticulous all over these months (Cranmer and Pocklington 2021, pp. 261-68). ${ }^{19}$ In some Latin-American countries, such as Argentina or Peru, the irregular itinerary of governmental rules and their interpretation moved to order a severe prohibition of worship, including individual worship in temples and the administration of sacraments in private homes, with the consequence that part of Catholic bishops felt obliged to close the churches (Navarro Floria 2021, pp. 312-22; Flores Santana 2021, pp. 495-97).

In general, most religious communities showed a high degree of responsibility and respect for the relevant governments' rules and guidelines. Some churches suspended open-air ceremonies with deep popular roots, such as Holy Week processions in Mexico and Spain (Patiño Reyes 2021, pp. 465-69; Rodrigo Lara 2021, pp. 138-40). Moreover, at least at the beginning, religious communities did not discuss restrictions on worship and focused on making their own rules and praxis more flexible in order to keep pursuing their mission through alternative ways, including the use of contemporary communication technologies to broadcast religious ceremonies or to provide religious instruction and religious assistance ${ }^{20}$ (which some churches have also applied to the collection of money offerings in temples).

Such deference of religious communities to governments has not always received a positive judgment by scholars. For instance, a Uruguayan scholar has maintained that the Catholic bishops of his country were too subservient in their acritical obedience to governmental policies and did not take sufficiently into account the mediumterm impact that such policies could have on the religious freedom of Catholic citizens (González Merlano 2021, p. 518). In any event, the attitude of a number of religious communities has been changing as the urgency faded away with the passage of time and many governments kept taking their decisions about such important issues in small and closed circles, without hardly any real contact with the civil society's main actors-not even with the most authoritative voices that, from a constitutional perspective, could provide guidance to the government not only about what was reasonable or unreasonable but also about what was respectful or abusive in relation to fundamental freedoms.

Thus, from the initial unconditional support, religious communities have been changing to more critical positions in many places, especially due to the lack of dialogue and comprehension of the significance of religious worship, or because religious organizations felt unfairly discriminated in comparison with other entities or activities. A very illustrative example is the comportment of Colombia's Bishops Conference, which passed from the full endorsement of the government in early March 2020 to demand, about six weeks later, more flexible limitations on religious worship in parallel with the rules applicable to other secular activities (Prieto 2021, pp. 400-2, 409-10). Nevertheless, particularly traditional

19 Updated and detailed information on the Church of England and the UK regulations can be found in the blog Law \& Religion UK (https: / /lawandreligionuk.com) (accessed on 11 May 2021).

20 These practices have become rapidly spread all over the world. In Europe, see for instance, (Fortier 2021, p. 153; Brzozowski 2021, pp. 200-5). 
churches and religious communities have made this criticism compatible with the respect for precautionary measures aimed at avoiding contagion - for instance, keeping carefully an appropriate safety distance between persons, cleaning scrupulously the inside of temples and places of prayer, and hygienic measures such as providing disinfectant solution at the entrance, removing the holy water, or giving the holy communion always in the hand instead of in the tongue.

Naturally, the positioning of religious communities vis-à-vis governmental measures has depended much on their own internal organization and structure; the more centralized and hierarchical it was, the more uniform the reaction of the relevant religious community has been. However, there have been exceptions, the most significant being probably the different attitudes adopted by the Vatican and the Italian Bishops Conference-the former very deferential to the government, the latter very critical to it (Consorti 2021, pp. 180-82; Cavana 2021, pp. 285-98). Another important factor has been the severity of the restrictions on worship and religious assistance adopted in various countries, as well as the procedure that was followed to decide them-as could be expected, the more consultation of the government with religious communities, the more easily the restrictive measures were accepted and respected. Therefore, the panorama of the different countries in Europe and America offers significant variations in the attitudes of religious communities. We can identify trends towards collaboration (more or less active), perplexity accompanied by resignation, resistance, or even plain objection. ${ }^{21}$

Nonetheless, by and large it is fair to say that the tendency in religious communities has not been a systematic blind opposition to limitations that appeared reasonable from the perspective of the protection of public health. In most countries the tendency has been rather to seek a dialogue with the government with two aims. On the one hand, reaching consensus on the limitations that should be imposed. On the other hand, ensuring that the religious communities' point of view was considered and they were not discriminated as a result of a superficial assessment of the importance of the freedom of worship, or of an arbitrary application of the rules.

Indeed, when tensions have led to litigation, the element of arbitrariness has been central in some jurisdictions, as in some lawsuits pursued in Chile (Celis Brunet and Castro 2021, pp. 388-94), while in others, such as Germany, the core issue has been the interpretation of the principle of proportionality (Testa Bappenheim 2020). The responses of the courts have been different depending on the countries. Significantly, however, within the same country, the courts' approach has sometimes changed depending on the moment that the claim was decided.

A decision of the Supreme Court of the United States of America, Cuomo, rendered in November 2020, illustrates such change of direction. Unlike what had occurred in previous similar occasions, ${ }^{22}$ in this case the Supreme Court granted the injunctive relief requested by a Catholic diocese and an Orthodox Jewish association against an executive order issued by the governor of New York. According to that executive order, no more than 10 or 25 persons-depending on the risk classification of the relevant zone-could attend a religious service, irrespective of the capacity of the temple. This restriction contrasted with the more benevolent treatment received by other secular businesses that provided services deemed "essential", such as, for example, liquor stores, hardware stores or acupuncture facilities. The Court recognized that its justices were not experts in public health and nevertheless they must demand that the executive power provided a convincing and compelling reason to subject a fundamental right to such severe restrictions, which were not comparable to limitations imposed on activities that involved an apparently equivalent risk. Together with the principle of equal treatment, the time factor was considered by the Court of the utmost importance. Giving carte blanche to the executive might have had sense at the beginning of the pandemic, for urgent action was needed and there were still

21 See, for instance, the examples provided by (Bussey 2021, pp. 52-64), as well as by the chapters on the American countries in (Martínez-Torrón and Lara 2021).

22 For some interesting comments on the precedent decisions of the Supreme Court on comparable claims in 2020, see (Madera 2020; also Durham 2020). 
many uncertainties about how the coronavirus spread. However, more than half a year later, such deference with the executive's discretionary powers was not compatible with the guarantee of constitutional rights. ${ }^{23}$

More recently, the Supreme Court of Chile has delivered a unanimous decision in a similar direction in a claim that involved the celebration of the Catholic Holy Mass. Emphasizing the significance of religious freedom, the need to carefully justify restrictions on this fundamental freedom, and that manifestations of religions should be treated on equal terms in comparison with other activities conducted in public, the Court held that public authorities should foresee a system of authorizations similar to those granted for other activities. ${ }^{24}$ Also, the Outer House of the Court of Session in Scotland has taken an analogous approach, with a strict scrutiny of the proportionality of the measures ordered by the Scottish government in the light of article 9 of the European Convention on Human Rights. $^{25}$

Needless to say, the history of the reactions to COVID-19 for religious reasons continues as far as the pandemic subsists. And new fronts have appeared when the vaccines have commenced to be distributed, especially if vaccination is made mandatory at a certain point, either because governments so decide or because, for example, employers impose it to employees. ${ }^{26}$

Conscientious objection to vaccination has existed for a long time, normally for religious reasons, as well as objections on other grounds. In the USA and Australia, some movements of religious inspiration resisting the COVID-19 vaccination have already emerged. ${ }^{27}$ The traditional legal response in these cases has been to justify restrictions on the objectors religious freedom by giving priority to the protection of public health; even if the individual's right to reject a medical treatment on religious grounds is recognized, such right must yield when the lives of other people may be endangered because of a risk of contagion. ${ }^{28}$ Such reasoning seems certainly sensible, for nobody is entitled to put anyone else's life at risk as a consequence of a personal moral decision regarding vaccination.

However, we must not forget that this judicial doctrine was declared with regard to vaccines that were considered safe and necessary at the time. Therefore, it should be taken with caution in the case of anti-COVID-19 vaccines, in view of the unusual speed with which currently existing vaccines have been developed and approved, as well as the ongoing scientific debate about their actual efficiency and negative collateral effects for some people-in occasions possibly lethal. Moreover, the percentage of the population that oppose vaccination on religious grounds is very low. In other words, when there are still so many uncertainties and controversy about the anti-COVID-19 vaccines, making vaccination mandatory may seem an extreme and disproportionate measure, and even

23 Roman Catholic Diocese of Brooklyn v. Cuomo, 592 U.S. ___ (2020) (25 November 2020, per curiam). The decision was taken by five votes to four. For a quick and incisive comment, vid. (McConnell and Raskin 2020). Later, the Supreme Court decided in a similar direction the (somewhat more complex) case South Bay United Pentecostal Church et al. v. Newsom, 592 U.S.__ (2021) (5 February 2021).

24 Judgment of the Supreme Court of Chile (Third Chamber), 29 March 2021 (Rol 19062-2021).

25 Philip \& Ors for Judicial Review of the closure of places of worship in Scotland, (2021) CSOH 32.

26 The relationship between religious freedom and vaccination is analysed, from a comparative perspective, by Meseguer Velasco 2021, which I could read thanks to the author's courtesy.

27 (See Scharffs 2021, pp. 439-40). See also, for instance: https://www.dailymail.co.uk/news/article-2915544/No-jab-no-play-Victoria-second-statemake-vaccinations-compulsory-children-day-care.html (accessed on 11 May 2021). In Australia, before COVID-19, the issue was discussed by (Barker 2017).

28 See, more than one century ago, the US Supreme Court judgment Jacobson v. Massachusetts, 197 U.S. 11 (1905), denying exemption from the smallpox vaccination requirement. Its doctrine has been reiterated in various subsequent judgments of the Supreme Court with particular clarity-although the case was not related to vaccination but to child labor laws-in Prince v. Massachusetts (1944), where the Court said: "The right to practice religion freely does not include liberty to expose the community or the child to communicable disease" (321 U.S. 158, at 166-67). 
more if it means to override the freedom of conscience of an insignificant minority of citizens. $^{29}$

A different type of conscientious objection has also been raised not to vaccination per se but to specific types of vaccines, because in their research and development cell lines from electively aborted foetuses have been utilized. These vaccines have raised a moral dilemma, especially in Christians, some of whom hesitated to accept those vaccines thinking that it might constitute material passive cooperation with abortion. ${ }^{30}$

In response to that concern, in December 2020, the Holy See's Congregation for the Doctrine of the Faith published a tranquilizing note approved by Pope Francis, stating that accepting inoculation with those vaccines is morally acceptable-the greater good of containing the pandemic makes such a remote and indirect cooperation in evil licit. ${ }^{31}$ The same note made clear that this should not be understood as any kind of moral endorsement of the use of cell lines proceeding from aborted foetuses-indeed, the note encourages pharmaceutical companies and governmental health agencies to "produce, approve, distribute and offer ethically acceptable vaccines that do not create problems of conscience for either health care providers or the people to be vaccinated". 32 The note also declared that vaccination should be voluntary, but it remarked that those persons who in any event consider that type of vaccine as morally unacceptable must do their utmost to avoid, by other means, becoming agents for the transmission of the virus. ${ }^{33}$ With this note, the Vatican has adopted a very flexible and deferential position vis-à-vis governmental choices in the matter, instead of pressuring and urging governments to choose and promote those vaccines that have been developed using resources that accommodate the moral standards of Catholic doctrine.

\section{Concluding Remarks}

At the beginning of these pages, I mentioned that the COVID-19 pandemic has harshly revealed our vulnerability, both as individuals and as community, and has brought to light the best and the worst in us. Depending on whom we look at, we have witnessed incredible acts of altruism, generosity and dedication, in parallel with the desire of taking unfair advantage of the situation-with the latter I refer of course to criminal activities, but we may probably include also the enormous business made with the occasion of medical supplies, protection masks, disinfectants, lab tests, etc., with oscillations in prices that were not certainly moved by philanthropy.

The foregoing is relevant when we ask ourselves what will remain in our societies after the pandemic passes. What will the world after COVID-19 be like?

It has been pointed out that, on the positive side, the coronavirus crisis may lead hopefully "to a new sense of community", considering the feeling of shared responsibility and the many expressions of solidarity generated in a large amount of people during the pandemic, especially in the first months. However, other people have started looking at fellow human beings as a danger, as far as they are potential carriers of the virus, which has led frequently to social distancing - not just physical distancing as a precaution- "as well as growing isolation and loneliness, especially among mentally unstable individuals". ${ }^{34}$

29 The interest in the issue of objection to vaccination has been revived by the recent judgment of the European Court of Human Rights Vavřčka and others v. The Czech Republic (Grand Chamber, 8 April 2021, App. no. 47621/13 and five others), which involved the opposition of some parents to comply with the State's policies about vaccination of children. The Court decided in favour of the respondent State, but I find particularly convincing the remarks made by Judge Wojtyczek in his dissenting opinion, arguing for a stricter scrutiny of the factual reasons that supported governmental policies that imposed health measures on children against the parents' wishes, as well as in favour of a proper analysis of the implications that this type of case may have for freedom of conscience.

30 See, for instance: https://blogs.bmj.com/medical-ethics/2020/04/09/covid-19-and-vaccine-ethics-pre-empting-conscientious-objection/ (accessed on 11 May 2021).

31 Note of the Congregation for the Doctrine of the Faith on the morality of using some anti-Covid-19 vaccines, 21 December 2020. Available in: https://press.vatican.va/content/salastampa/en/bollettino/pubblico/2020/12/21/201221c.html (accessed on 11 May 2021).

32 (Ibid., para. 4).

33 (See ibid., para. 5).

34 (See Kortmann and Schulze 2021, p. 35). From the same authors, see the interdisciplinary book (Kortmann and Schulze 2020) 
At the end of the day, the scientific challenges posed by COVID-19 may be new to a large extent, but when we look for solutions to the social problems it has caused, our best bet is likely on traditional means. From a legal perspective, we need a scrupulous respect for the requirements of the rule of law, with especial emphasis on the protection of fundamental rights, among which is freedom of religion or belief. Every limitation on a fundamental right must be precisely justified and must carefully follow the appropriate procedure, avoiding the temptation to trivialize the guarantee of what are actually the pillars of a democratic society. Allowing that an exceptional health crisis results in a lack of accountability of governments vis-à-vis the citizens would be one of the most undesirable outcomes of the pandemic. And, from a broader social perspective, in addition to the gigantic welfare machinery of the State, we must rely on the traditional resources of society-also its ethical resources, of which religious communities are an integral and essential part.

Religious freedom is one of the vital freedoms that should not be easily dispensed with, not even in times of emergency, and religious communities-which represent the collective exercise of this fundamental right-are a unique and valuable resource that society has at its disposal to fight against critical threats. These are two lessons that the COVID-19 pandemic has taught us, and we should take a good note of them for possible future extraordinary crises. If we apply them also to ordinary situations, it would be even better.

Funding: This research was done during my stay as a Senior Fellow and Marie-Curie Fellow of the European Union at FRIAS (Freiburg Institute for Advanced Studies), 2020-2021. This paper has been written in the context of the Project HUDISOC (PID2019-106005GB-I00) of the Spanish Ministry of Science and Innovation.

Institutional Review Board Statement: Not applicable.

Informed Consent Statement: Not applicable.

Data Availability Statement: Not applicable.

Acknowledgments: I would like to express here my gratitude to Roland Muntschick, Assistant at FRIAS, for his diligent and efficient editing work of this paper.

Conflicts of Interest: The author declares no conflict of interest.

\section{References}

Balsamo, Fabio, and Daniela Tarantino, eds. 2020. Law, Religion and the Spread of COVID-19 Pandemic. DiReSoM Papers 2. Pisa: DiReSoM, Available online: https:/ / diresom.net/category/ebook/ (accessed on 11 May 2021).

Barker, Renae. 2017. No Jab-No Pay, No Jab-No Play, No Exceptions: The Removal of Conscientious and Religious Exemptions from Australia's Childhood Vaccination Policies. Quaderni di Diritto e Politica Ecclesiastica 25: 513-26.

Besson, Samantha. 2012. Evolutions on Non-Discrimination Law within the ECHR and ESC Systems: It Takes Two to Tango in the Council of Europe. American Journal of Comparative Law 60: 147-80. [CrossRef]

Brzozowski, Wojciech. 2021. Polonia: La libertad religiosa en tiempos de la pandemia del COVID-19. In COVID-19 y Libertad Religiosa. Edited by Javier Martínez-Torrón and Belén Rodrigo Lara. Madrid: Iustel, pp. 183-210.

Bussey, Barry W. 2021. Contagio: El temor de los gobiernos a la religión durante la crisis del COVID-19. In COVID-19 y Libertad Religiosa. Edited by Javier Martínez-Torrón and Belén Rodrigo Lara. Madrid: Iustel, pp. 37-72.

Cañamares Arribas, Santiago. 2019. Ministros de culto y autonomía confesional en la jurisprudencia del Tribunal Europeo de Derechos Humanos. In Libertad Religiosa, Neutralidad del Estado y Educación. Una Perspectiva Europea y Latinoamericana. Edited by Javier Martínez-Torrón and Santiago Cañamares Arribas. Madrid: Thomson Reuters Aranzadi, pp. 81-100.

Cavana, Paolo. 2021. Libertad religiosa y COVID-19 en el Vaticano y en la acción de la Santa Sede. In COVID-19 y Libertad Religiosa. Edited by Javier Martínez-Torrón and Belén Rodrigo Lara. Madrid: Iustel, pp. 279-304.

Celis Brunet, Ana María, and René Cortínez Castro. 2021. Religión y Coronavirus: Los desafíos en Chile en tiempos de estado de excepción constitucional. In COVID-19 y Libertad Religiosa. Edited by Javier Martínez-Torrón and Belén Rodrigo Lara. Madrid: Iustel, pp. 377-96.

Christians, Louis-Léon, and Adriaan Overbeeke. 2021. El Derecho belga sobre los grupos religiosos frente al desafío de la crisis sanitaria del COVID-19. Normativa de crisis entre viejos reflejos y nuevas realidades. In COVID-19 y Libertad Religiosa. Edited by Javier Martínez-Torrón and Belén Rodrigo Lara. Madrid: Iustel, pp. 97-118. 
Consorti, Pierluigi, ed. 2020a. Law, Religion and COVID-19 Emergency. DiReSoM Papers 1. Pisa: DiReSoM, Available online: https:/ / diresom.net/category/ebook/ (accessed on 11 May 2021).

Consorti, Pierluigi. 2020b. Religions and virus. In Law, Religion and COVID-19 Emergency. Edited by Pierluigi Consorti. Pisa: DiReSoM, pp. 15-18.

Consorti, Pierluigi. 2021. Emergencia y libertad religiosa en Italia frente al miedo a la COVID-19. In COVID-19 y Libertad Religiosa. Edited by Javier Martínez-Torrón and Belén Rodrigo Lara. Madrid: Iustel, pp. 167-82.

Cranmer, Frank, and David Pocklington. 2021. El impacto de la pandemia de COVID-19 en la práctica religiosa en Reino Unido. In COVID-19 y Libertad Religiosa. Edited by Javier Martínez-Torrón and Belén Rodrigo Lara. Madrid: Iustel, pp. 241-78.

Durham, W. Cole, Jr. 2020. The Coronavirus, The Compelling State Interest in Health, and Religious Autonomy. Canopy Forum. October 2. Available online: https:/ / canopyforum.org/2020/10/02/the-coronavirus-the-compelling-state-interest-in-healthand-religious-autonomy / (accessed on 11 May 2021).

El Cronista del Estado Social y Democrático de Derecho. 2020. pp. 86-87. Available online: https://www.iustel.com/v2/revistas/detalle_ revista.asp?numero $=86 \&$ id $=16$ (accessed on 11 May 2021).

European Court of Human Rights. 2020. Guide on Article 14 of the Convention (Prohibition of Discrimination) and on Article 1 of Protocol No. 12. Available online: https:/ / www.echr.coe.int/Documents/Guide_Art_14_Art_1_Protocol_12_ENG.pdf (accessed on 11 May 2021).

Fattori, Gabriele. 2020. Religious freedom at the time of coronavirus. In Law, Religion and COVID-19 Emergency. Edited by Pierluigi Consorti. Pisa: DiReSoM, pp. 57-64.

Flores Santana, Gonzalo. 2021. El respeto a la libertad religiosa en las políticas sanitarias del gobierno frente al coronavirus en el Perú. In COVID-19 y Libertad Religiosa. Edited by Javier Martínez-Torrón and Belén Rodrigo Lara. Madrid: Iustel, pp. 491-512.

Fortier, Vincente. 2021. La libertad de religión, en Francia, en tiempos de coronavirus. In COVID-19 y Libertad Religiosa. Edited by Javier Martínez-Torrón and Belén Rodrigo Lara. Madrid: Iustel, pp. 145-66.

González Merlano, Gabriel. 2021. La libertad religiosa en Uruguay durante la pandemia. Entre el derecho fundamental y el espectáculo público. In COVID-19 y Libertad Religiosa. Edited by Javier Martínez-Torrón and Belén Rodrigo Lara. Madrid: Iustel, pp. 513-35.

Gunn, Jeremy. 2005. Deconstructing Proportionality in Limitations Analysis. Emory International Law Review 19: 465-98.

Introvigne, Massimo. 2020. Lesson from the Shincheonji Case in South Korea: Monitoring without Scapegoating. In Law, Religion and COVID-19 Emergency. Edited by Pierluigi Consorti. Pisa: DiReSoM, pp. 145-50.

Johnson, Niall A. P. S., and Jürgen Müller. 2005. Updating the Accounts: Global Mortality of the 1918-1920 "Spanish" Influenza Pandemic. Bulletin of the History of Medicine 76: 105-15. [CrossRef] [PubMed]

Kortmann, Bernd, and Günther G. Schulze, eds. 2020. Jenseits von Corona: Unsere Welt nach der Pandemie-Perspektiven aus den Wissenschaft. Bielefeld: Transcript.

Kortmann, Bernd, and Günther G. Schulze. 2021. The Post-COVID World. Deutschland Edition. Available online: https://www. deutschland.de/en/fighting-corona-together-magazine-available-for-free-download (accessed on 11 May 2021).

Madera, Adelaide. 2020. Reconciling the Protection of Public Health with Religious Freedom: The Viability of Shared Responses. In Law, Religion and the Spread of COVID-19 Pandemic. Edited by Fabio Balsamo and Daniela Tarantino. Pisa: DiReSoM, pp. 213-25.

Martínez-Torrón, Javier, and Belén Rodrigo Lara, eds. 2021. COVID-19 y Libertad Religiosa. Madrid: Iustel.

Martínez-Torrón, Javier. 2005. Limitations on Religious Freedom in the Case Law of the European Court of Human Rights. Emory International Law Review 19: 587-636.

Martínez-Torrón, Javier. 2015. La neutralidad religiosa del Estado. In Historia y Constitución. Edited by Miguel Carbonell Sánchez and Óscar Cruz Barney. México: Instituto de Investigaciones Jurídicas de la UNAM, vol. 2, pp. 313-39.

Martínez-Torrón, Javier. 2018. State Neutrality and Religious Plurality in Europe. In Religion, Pluralism, and Reconciling Difference. Edited by W. Cole Durham Jr. and Donlu D. Thayer. New York: Routledge, pp. 159-76.

McConnell, Michael, and Max Raskin. 2020. The Supreme Court Was Right to Block Cuomo's Religious Restrictions. The New York Times. December 1. Available online: https:/ / www.nytimes.com/2020/12/01/opinion/supreme-court-Covid-19-religion.html (accessed on 11 May 2021).

Meseguer Velasco, Silvia. 2019. La Financiación de la Religión en Europa. Madrid: Digital Reasons.

Meseguer Velasco, Silvia. 2021. Libertad religiosa, salud pública y vacunación COVID-19. Revista General de Derecho Canónico y Derecho Eclesiástico del Estado, 56, forthcoming.

Ministero de la Justicia, ed. 2009. Comisión Asesora de Libertad Religiosa: Realidad y Future. Madrid: Ministero de la Justicia.

Mückl, Stefan. 2021. Libertad religiosa y COVID-19: La situación en Alemania. In COVID-19 y Libertad Religiosa. Edited by Javier Martínez-Torrón and Belén Rodrigo Lara. Madrid: Iustel, pp. 73-96.

Navarro Floria, Juan G. 2021. La pandemia y la libertad religiosa en la Argentina: Algunas reflexiones. In COVID-19 y Libertad Religiosa. Edited by Javier Martínez-Torrón and Belén Rodrigo Lara. Madrid: Iustel, pp. 305-52.

Navarro-Valls, Rafael. 2008. Neutralidad activa y laicidad positiva. In Laicismo y Constitución. Edited by A. Ruiz Miguel and Rafael Navarro-Valls. Madrid: Fundación Coloquio Jurídico Europeo, pp. 97-145.

Palomino, Rafael. 2014. Neutralidad del Estado y Espacio Público. Navarra: Thomson Reuters Aranzadi.

Patiño Reyes, Alberto. 2021. Libertad religiosa ante la pandemia por el COVID-19 en México. In COVID-19 y Libertad Religiosa. Edited by Javier Martínez-Torrón and Belén Rodrigo Lara. Madrid: Iustel, pp. 459-90.

Payne, Heather, and Norman Doe. 2005. Public Health and the Limits of Religious Freedom. Emory International Law Review 19: 539-55. 
Picciaredda, Stefano. 2020. Covid-19 in Africa and Latin America. Certain forms of religious negationism favor the pandemic. In Law, Religion and the Spread of COVID-19 Pandemic. Edited by Fabio Balsamo and Daniela Tarantino. Pisa: DiReSoM, pp. 129-40.

Prieto, Vicente. 2021. Pandemia y límites a la libertad religiosa. El caso colombiano. In COVID-19 y Libertad Religiosa. Edited by Javier Martínez-Torrón and Belén Rodrigo Lara. Madrid: Iustel, pp. 397-414.

Raimundo, Miguel Assis, Paulo Pulido Andragão, Anabela Costa Leão, and Tiago Ramalho. 2021. COVID-19 y libertad religiosa en Portugal. In COVID-19 y Libertad Religiosa. Edited by Javier Martínez-Torrón and Belén Rodrigo Lara. Madrid: Iustel, pp. 211-40.

Rodrigo Lara, Belén. 2021. La libertad religiosa en España durante la pandemia de COVID-19. In COVID-19 y Libertad Religiosa. Edited by Javier Martínez-Torrón and Belén Rodrigo Lara. Madrid: Iustel, pp. 119-44.

Scharffs, Brett G. 2021. El coronavirus y la libertad religiosa: Un análisis preliminar de los Estados Unidos. In COVID-19 y Libertad Religiosa. Edited by Javier Martínez-Torrón and Belén Rodrigo Lara. Madrid: Iustel, pp. 415-58.

Sieira Mucientes, Sara. 2020. Estado de alarma. Eunomía. Revista en Cultura de la Legalidad 19: 275-305. [CrossRef]

Soler Martínez, José Antonio. 2020. Estado de alarma y libertad religiosa y de culto. Revista General de Derecho Canónico y Derecho Eclesiástico del Estado 53: 1-40.

Souza Alves, Rodrigo Vitorino, Andréa Letícia Carvalho Guimarães, José Renato Prata Resende, and Gabriellen da Silva Xavier do Carmo. 2021. La libertad de religión o de creencias y la pandemia del COVID-19. Análisis de las medidas restrictivas adoptadas en Brasil. In COVID-19 y Libertad Religiosa. Edited by Javier Martínez-Torrón and Belén Rodrigo Lara. Madrid: Iustel, pp. 353-76.

Testa Bappenheim, Stefano. 2020. State of emergency and religious freedom: Constitutional stress in German law (art. 4 of the Basic Law for the Federal Republic of Germany. In Law, Religion and the Spread of COVID-19 Pandemic. Edited by Fabio Balsamo and Daniela Tarantino. Pisa: DiReSoM, pp. 227-54.

Valero Estarellas, María José. 2017. Neutralidad del Estado y Protección de la Autonomía Religiosa en Europa. Ph.D. Thesis, Universidad Complutense de Madrid, Madrid, Spain. Available online: https://eprints.ucm.es/id/eprint/47989/1/T40016.pdf (accessed on 11 May 2021).

Valero Estarellas, María José. 2019. Autonomía de las confesiones religiosas, neutralidad del Estado y prohibición de arbitrariedad, en la reciente jurisprudencia del Tribunal Europeo de Derechos Humanos. In Libertad Religiosa, Neutralidad del Estado y Educación. Una Perspectiva Europea y Latinoamericana. Edited by Javier Martínez-Torrón and Santiago Cañamares Arribas. Madrid: Thomson Reuters Aranzadi, pp. 55-79.

van den Vyver, Johan D. 2005. Limitations on Freedom of Religion or Belief: International Law Perspectives. Emory International Law Review 19: 499-537. 